\title{
In vivo and in vitro studies to evaluate nutritional value of Chenopodium quinoa as unconventional forage resource for feeding ruminants
}

\author{
Yacout M. H. ${ }^{\text {a }}$, Salama R. ${ }^{\text {, }}$ Elgzar M. I. T. ${ }^{\mathrm{a}}$, Awad A. A. ${ }^{\text {** }}$ \\ ${ }^{a}$ Animal Production Research Institute, Agriculture Research Center, Dokki, Giza, Egypt \\ ${ }^{b}$ Animal Production Department, Faculty of Agriculture, Al-Azhar University, Cairo, Egypt
}

\begin{abstract}
The present study was carried out to justify the nutritional value of quinoa hay or silage as unconventional forage source for feeding ruminants in compare with the ordinary berseem hay and corn silage. Two silages were examined, corn silage (CS) and quinoa silage (QS) and two hays; Berseem hay (BH) and Quinoa hay $(\mathrm{QH})$ as roughages. Barley grains $(\mathrm{BG})$ as concentrate $(500 \mathrm{~g} / \mathrm{h} /$ day) with each of the previous rations was used to formulate four nutritional treatments in feeding experimental animals. Twelve adult Barki rams were used in digestibility trails ( 3 for each), while another three Barki adult ewes fitted with permanent rumen fistula were used in rumen fermentation and in situ study. Experimental animals were fed as above in the digestibility trials. The obtained results can be summarized as follow: Results showed that $\mathrm{pH}$ values of corn and quinoa silages at the opening time were 4.02 and 4.36, respectively with higher TVFA's concentration, and lower ammonia- $\mathrm{N}$ concentration, which could be considered as a good indicator of silage characteristics for both of quinoa and corn. Lactic and acetic acids were highest for corn silage in compare with quinoa silage. Digestion coefficient of DM, OM, CP and nutritive values in terms of (TDN\% and DCP \%) were significantly $(\mathrm{P}<0.05)$ higher for corn silage and berseem hay rations compared with quinoa in both forms. Berseem hay was the higher $\mathrm{pH}$ value without significant difference $(\mathrm{P}>0.05)$, among different groups. Ammonia-N concentration $(\mathrm{mg} / 100 \mathrm{ml})$, rate of $\mathrm{NH}_{3}-\mathrm{N}$ production $(\mathrm{mg} / 100 \mathrm{ml} / \mathrm{hr})$, and mean values of rate of out flow (\%hr) from rumen of ewes fed quinoa hay or quinoa silage were higher $(\mathrm{P}<0.05)$ than those fed berseem hay and corn silage. On the contrarily, ewes fed berseem hay and corn silage, recorded higher $(\mathrm{P}<0.05)$ TVFA's concentration (meq/ $100 \mathrm{ml})$, higher rate of production $(\mathrm{meq} / 100 \mathrm{ml})$, besides higher rumen volume (L) than those fed quinoa hay or silage. Berseem hay ration and corn silage recorded the higher $(\mathrm{P}<0.05)$ microbial nitrogen synthesis $(\mathrm{MN} \mathrm{g} / \mathrm{d})$, in compare with quinoa hay and silage. And while $\mathrm{pH}$ value, ruminal volume, and microbial nitrogen synthesis $(\mathrm{MN} \mathrm{g} / \mathrm{d})$, tended to decrease $(\mathrm{P}<0.05)$ with the advancing time of sampling; $\mathrm{NH}_{3}-\mathrm{N}(\mathrm{mg} / 100 \mathrm{ml})$, tended to increase $(\mathrm{P}<0.05)$.
\end{abstract}

Keywords: quinoa, corn, silage, forage, ruminants. 


\section{Introduction}

In Egypt, the shortage in animal feedstuffs during summer period represents a significant problem. Most of the available feed residues introduced to animals are characterized by their poor quality, low palatability, low intake and low protein content. Corn plant is one of the main crops in Egypt; about 2 million feddans are cultivated annually with corn plants (Zedan, 1998). The corn stalks are characterized by low levels of protein (3$6 \%$ ), digestible materials, energy and minerals, however it contains a high percentage of fiber and lignin (Church, 1980). However, it is possible to conserve them for use during periods of which there is a feed shortage. In European countries more than $90 \%$ of the forages locally produced are stored as silage, and even in countries with generally good weather conditions for hay making, approximately. $50 \%$ of the forage is ensiled (Wilkinson et al., 1996). The ensiling of by-products is simple and being an appropriate method for conservation. It is the most effective way to improve animal feed resources through the rational use of locally available agricultural by-products likely to be available to small-scale farmers at village level quinoa (Chenopodium quinoa Willd.) is a pseudocereal native to South America. It was an important staple food in the incient civilization and has been cultivated in the Andean highlands since $3,000 \mathrm{BC}$. In recent years, there has been renewed interest in quinoa because of its unique and interesting properties. Its starch exists as very small granules and is reported to be low in amylose (Lorenz, 1990). Its protein content and quality, with an amino acid profile similar to that of casein, are high compared to those of true cereals. Quinoa leaves are widely used as food for humans and livestock (Weber, 1978) and constitute an inexpensive source of vitamins and minerals. Chenopodium leaves have more protein and minerals than commonly consumed spinach and cabbage, but less than amaranth leaves. Quinoa requires short day lengths and cool temperatures for good growth. This crop is somewhat drought tolerant with a water requirement of 10 to 15 in. per year. Nowadays this crop was grown in Green Egypt desert society in Wady-elnatron city. Quinoa (Chenopodium quinoa) could be a valuable forage crop for dairy farms when used as quinoa hay or ensiled, with good yields and high protein content. This study was conducted to evaluate quinoa silage quality, digestion coefficients, nutritive values and how it can be introduced as new forage either as hay or silage in Egypt compared to berseem hay or corn silage.

\section{Materials and methods}

The present study was carried out in Noubariya Experimental Station, belongs to the Animal Production Research Institute, Ministry of Agriculture, Egypt in cooperation with Animal Production Department, Faculty of Agriculture, AlAzhar University, Egypt through the period (2017-2018). 


\subsection{Quinoa and corn silage preparation}

Quinoa was harvested before seed setting (after 90 days), chopped into $0.5-2.0$ $\mathrm{cm}$. pieces to make a whole crop silage (WCS). The chopped plants (quinoa or corn) were ensiled on the ground in two horizontal silo walls one for each crop with $(2 \times 3 \times 1.5 \mathrm{~m}$ each). Molasses was added at 5\% (on DM basis) to the whole quinoa stalks before ensiling to provide fast fermentable carbohydrates. In order to ensure good consolidation for each layer after filling; the whole silos were pressed by labor's feet, covered carefully by plastic sheet and pressed hardly by the soil and some stone blocks. The silos were opened for feeding after three months ensiling period. The two silos were opened from one side only. At the opening time, colour and odour were directly examined, and dry matter determination was conducted using drying oven at $105{ }^{\circ} \mathrm{C}$ for 24 hours. Representative samples were taken from corn and quinoa silage heaps to measure $\mathrm{pH}$ (immediately), using digital $\mathrm{pH}$ and other samples were stored frozen at (- 20 ${ }^{0} \mathrm{c}$ ) to be used later for chemical analysis. The concentrations of TVFA's were determined according to the method of Warner (1964). Ammonia- N, lactic acid and individual VFA's were analyzed according to the methods described by Everson et al. (1971). Neutral detergent fiber (NDF), acid detergent fiber (ADF) and acid detergent lignin (ADL) were analyzed by the method of Van Soest
(1991). Cellulose and hemicellulose were accordingly predicted.

\subsection{Quinoa and berseem hay preparation}

Quinoa stalks were harvested at 90 days, spread on ground in rows and layers of range $10-25 \mathrm{~cm}$ height. Berseem $\left(3-4^{\text {th }}\right.$ cuts) was cut to $10 \mathrm{~cm}$ in length far from land and spread on ground in rows and layers of range $10-25 \mathrm{~cm}$ height. Quinoa and berseem were turned upside down every day, after dew disappearance until used in feeding animals for digestibility trials. Samples were taken from each hay for chemical analysis.

\subsection{Digestibility trials}

Twelve adult Barki Rams were randomly assigned into four digestibility groups to be fed one of the following tested rations, besides $500 \mathrm{gm}$ barley grains $/ \mathrm{h} / \mathrm{d}: \mathrm{R}_{1}$; Berseem hay $(\mathrm{BH})$ and served as a control $\left(\mathrm{C}_{1}\right), \mathrm{R}_{2}$; quinoa hay $(\mathrm{QH}), \mathrm{R}_{3}$; corn silage (CS) as a control $\left(\mathrm{C}_{2}\right)$ and $\mathrm{R}_{4}$; quinoa silage (QS). The trials lasted for three weeks as a preliminary period followed by one week as a collection period using three rams per each treatment. The digestibility trials were conducted as described by El-shazly (1958). Feed, feces and urine analysis were carried out according to the methods of AOAC (2012).

\subsection{Rumen fermentation and in situ trials}

Three adult Barki ewes fitted with 
permanent rumen fistula were used for rumen fermentation and in situ study. Animals were fed according to NRC recommendation (2007).

\subsection{Ruminal $\mathrm{pH}$ value}

Values of ruminal $\mathrm{pH}$ were measured immediately using $\mathrm{pH}$ meter (Orion).

\subsection{Concentration and rate of ammonia and volatile fatty acids production}

In vitro zero technique (Carrol and Hungate, 1954) was applied for measuring rates of ammonia and volatile fatty acids (VFA) production. Rumen contents were collected from the fistula before feeding then 1, 3 and 6 hours after feeding in jars $(500 \mathrm{ml})$ immersed in large beakers containing water at $39^{\circ} \mathrm{C}$. Samples were flushed with $\mathrm{CO}_{2}$ during the collection time, closed with a tightly fitting rubber with an out-let Bunsen valve and incubated at $39^{\circ} \mathrm{C}$ in thermostatically controlled water-bath. Each sample was composed of two thirds for fibrous material and one third of liquid (EI-Shazly and Hungate, 1965). At zero time, two sub-samples were poured into another jars containing formalin (1 $\mathrm{ml} / 100 \mathrm{~g}$ rumen contents) and swirled vigorously to stop metabolic activity. One sample was used to estimate ammonia-N and TVFA's concentration, while the other one was used to determine dry matter percentage in the rumen contents. After one-hour fermentation for the rumen contents, the jars were treated with formalin as described before, to estimate rates of ammonia and TVFA's production. Rumen samples were taken at zero and one hour of fermentation and strained through cheese cloth. Fifty $\mathrm{ml}$ of rumen liquor were deproteinized using sulphoric acid $(50 \mathrm{ml} \quad 0.1 \mathrm{~N})$ and volume was completed with water to $500 \mathrm{ml}$ in a volumetric flask and being filtered. The supernatant was used for determination of ammonia nitrogen using $(\mathrm{MgO})$ distillation method, (Al-Rabbat et al., 1971), while TVFA's were estimated using steam distillation as described by Warner (1964).

\subsection{Rumen volume, ruminal digesta and rate of out flow}

The colorimetric method of chromium ethylene diamine tetra acetate (cr-EDTA) according to the method of El-Shazly et al. (1976) was followed for rumen liquid volume determination. Rumen samples were collected through the rumen fistula before introducing the marker for blank determination and for preparation of a standard curves. An amount of cr-EDTA solution of $250 \mathrm{ml}$ of marker solution was warmed up to $40^{\circ} \mathrm{C}$, then introduced through the fistula at different sites in the rumen by the aid of a polyester tube; the rumen liquor samples were collected at 1 , 2, 3, 4, 5 and 6 hours after introducing the marker. Samples were strained through cheesecloth, then rumen volume was determined before feeding, 3 and 6 hours after feeding. 
2.7 Rates of digestion in the rumen (insitu study)

Nylon bags technique was used to determine the disappearance of dry matter, organic matter, nitrogen contents and crude fiber in the rumen, according to the methods described by Barrio et al. (1985). Two polyester bags (100\% dacron polyester) with a mean pore size of $45 \mu \mathrm{m}$ and the bags $(7 \times 15 \mathrm{~cm})$ had a surface area of about $210 \mathrm{~cm}^{2}$ were used at each incubation time. Approximately 3 $\mathrm{g}$ of ingredients were placed in each bag. Bags were incubated in the rumen of ewes and removed after 3, 6, 12, 24, 48 and $72 \mathrm{hrs}$. After the removal of bags, they were washed under a gently flowing steam of tap water until the fluid was clear. Bags were drained, dried for 24 hours at $105^{\circ} \mathrm{C}$, cooled in a desiccator and weighed. Dry matter, organic matter, nitrogen content and crude fiber were estimated according to the method of AOAC (2012).

\subsection{Microbial protein (MP) synthesis}

The microbial protein synthesized in the rumen of sheep fed the experimental rations were calculated as g MP per day using the model equation that has been justified by Borhami et al. (1992) as follow:

MP (gm) / day $=$ mole VFA produced $/$ day $\times 2 \times$ $13.48 \times 10.5 \times 6.25 / 100$

Mole TVFA produced $=$ rate TVFA $(\mathrm{meq}) \times 10 \times$ $24 \times$ Rumen digesta
Where: One mole VFA yield about 2 moles ATP (Walker, 1965). One mole ATP produce $13.48 \mathrm{Y}_{\text {atp }}$ (g dry matter microbial cell) (Borhami et al., 1979). N $\%$ of dry microbial cell $=10.5$ (Hungate, 1965).

\subsection{Statistical analysis}

Data were statistically analyzed using general linear method according to ANOVA procedures of SAS User Guide (2002). Duncan's multiple range test (1955) was applied to test the significant differences among means of traits. The following model was used:

$\mathrm{Y}_{\mathrm{ij}}=\mathrm{U}+\mathrm{T}_{\mathrm{i}}+\mathrm{e}_{\mathrm{ij}}$

Where $\mathrm{Y}_{\mathrm{ij}}=$ observation, $\mathrm{U}=$ overall mean, $T_{i}=$ effect of treatment and $e_{i j}=$ experimental error.

\section{Results and Discussion}

\subsection{Rations chemical composition}

Chemical composition of barley grains and experimental rations (on DM basis $\%)$ are shown in Table (1). The crude protein $(\mathrm{CP})$ content of Quinoa hay had much more $\mathrm{CP}$ content compared with Berseem hay (15.38\% vs. $12.47 \%)$, the same trend was observed for the silage form, whereas Quinoa silage contained $14.59 \% \mathrm{CP}$ compared to corn silage (8.39\%); Papastylianou et. al. (2014) reported a crude protein content of quinoa levels of $11.1-14.7 \% \mathrm{DM}$ in green matter for this plant. Crude fiber of 
quinoa hay was found to be faraway lower than that in berseem hay (11.60 vs. $22.73 \%$ ). The same finding was noticed in quinoa silage, when compared with corn silage (10.05 vs. 24.88\%), respectively. Ether extracted content was little pit more in quinoa hay than berseem hay ( 1.73 vs. $1.62 \%)$, but it was less in quinoa silage than in corn silage (1.78 vs.
1.97\%). Carbohydrate content expressed as NFE showed that quinoa either in the form of hay or silage could be found to be higher or more than berseem or corn. Ash content of quinoa was quiet similar in the form of hay or silage, if it compared to berseem or corn silage (9.07, 9.42 vs. 8.55 and $8.74 \%$, respectively).

Table (1): Chemical composition of barley grains and experimental rations (on DM basis \%).

\begin{tabular}{|l|c|c|c|c|c|}
\hline \multirow{2}{*}{ Item } & \multirow{2}{*}{ BG* } & \multicolumn{2}{|c|}{ Hay } & \multicolumn{2}{c|}{ Silage } \\
\cline { 3 - 6 } & & Berseem & Quinoa & Corn & Quinoa \\
\hline DM & 88.24 & 88.69 & 88.42 & 32.37 & 30.56 \\
\hline OM & 96.58 & 91.45 & 90.93 & 91.26 & 90.58 \\
\hline CP & 11.42 & 12.47 & 15.38 & 8.39 & 14.59 \\
\hline CF & 8.56 & 22.73 & 11.60 & 24.88 & 10.05 \\
\hline EE & 2.89 & 1.62 & 1.73 & 1.97 & 1.78 \\
\hline NFE & 73.71 & 54.63 & 62.22 & 56.02 & 64.16 \\
\hline Ash & 3.42 & 8.55 & 9.07 & 8.74 & 9.42 \\
\hline
\end{tabular}

$* \mathrm{BG}=$ Barley grain.

\subsection{Silage characteristics}

Results in Table (2) illustrated silage characteristics of quinoa and corn at zero and opening time. Values of $\mathrm{pH}$ showed that both silages had optimum $\mathrm{pH}$ values (4.02 and 4.36 for corn and quinoa, respectively). These could indicate for good quality silage. However, $\mathrm{pH}$ value for corn was found to be more acidic than that of quinoa. This could be related to the lower TVFA's and higher NH3-N concentration in quinoa than that of corn silage i.e (3.95 vs. $5.22 \mathrm{meq} / \mathrm{g}$ and 1.27 vs. $0.75 \mathrm{mg} / 100 \mathrm{ml})$, respectively. These results are in agreement with the findings of Zbigniew (2018), Hanafy (1985) and Tabana (1994), whereas total VFA's concentrations positively correlated with $\mathrm{pH}$ value in the silage. 
Table (2): Silage quality at zero time and opening day.

\begin{tabular}{|l|c|c|c|c|}
\hline \multirow{2}{*}{ Item } & \multicolumn{2}{|c|}{ Zero time } & \multicolumn{2}{c|}{ At open day } \\
\cline { 2 - 5 } & Corn silage & Quinoa silage & Corn silage & Quinoa silage \\
\hline DM (\%) & 29.68 & 26.89 & 32.37 & 30.56 \\
\hline TVFA's(meq/g) & 2.66 & 1.07 & 5.22 & 3.95 \\
\hline $\mathrm{pH}$ & 6.32 & 6.65 & 4.02 & 4.36 \\
\hline $\mathrm{NH}_{3}-\mathrm{N}, \mathrm{DM}(\%)$ & 0.14 & 0.44 & 0.75 & 1.27 \\
\hline Lactic acid, DM (\%) & 1.05 & 0.85 & 5.58 & 3.02 \\
\hline Acetic acid, DM (\%) & 0.77 & 0.98 & 3.88 & 3.06 \\
\hline Butyric acid, DM (\%) & 0.15 & 0.11 & 1.07 & 0.96 \\
\hline
\end{tabular}

Ammonia-N concentration was more in quinoa silage than in corn silage (1.27 vs. $0.75 \%$ of $\mathrm{DM}$ ), this could be related to the more $\mathrm{CP}$ content of quinoa than corn. It also could be due to the rapid decrease in $\mathrm{pH}$ value, (Abd El-Malik 1972; Hanafy, 1985; Tabana, 1994). Feed intake, digestion coefficients and nutritive values: Data presented in Table (3) showed feed intake, digestion coefficients and nutritive values of the experimental rations. Animals fed berseem hay and corn silage containing rations showed higher $(\mathrm{P}<0.05)$ daily feed intake compared to those fed rations contained, either quinoa silage or hay. However, the form of silage found to be more palatable than the hay form. The lower feed intake of quinoa hay could be related to its content of some antinutritional nutrients. Data of digestibility study could confirm the previous results of feeding corn silage compared to berseem hay or any other crop silages. Digestion coefficient of DM and OM was comparative in berseem hay and corn silage $(64.24,65.70$ and 64.05 and $64.95 \%$, respectively). No significant differences were found for the digestibility coefficients of DM and OM between rations contained either quinoa hay or silage. The higher $(\mathrm{P}<0.05)$ digestion coefficient of $\mathrm{CP}$ was noticed for animals fed corn silage $(63.01 \%)$ followed by those fed rations contained berseem hay $(61.27 \%)$ or quinoa silage (60.89\%). The lower CP digestion coefficient was found for quinoa hay containing diet $(59.48 \%)$. The higher $(\mathrm{P}<0.05) \quad \mathrm{CF}$ digestion coefficient was observed for sheep fed quinoa silage (61.35\%), followed by those fed ration contained quinoa hay $(59.51 \%)$. These could be due to its lower CF content $(11.60 \%$ in the quinoa hay and $10.05 \%$ in quinoa silage, Table 1). Digestion coefficient of $\mathrm{EE}$ was quiet similar for animals fed rations contained berseem hay $(65.37 \%)$, corn $(65.82 \%)$ and quinoa silage $(66.68 \%)$. Those fed quinoa hay containing rations recoded the lower EE digestion coefficient (62.94\%). These could be due to the high content of EE in corn and quinoa silage from one side and the higher degradation of berseem hay in the rumen from the other side. Higher $(\mathrm{P}<0.05) \quad$ NFE digestion coefficient $(68.66 \%)$ was found in animals fed berseem hay containing rations; the lower $(\mathrm{P}<0.05)$ NFE digestion coefficient 
value $(64.52 \%)$ was recorded for sheep fed quinoa silage. The higher digestion coefficient of NFE for berseem hay ration could be due to the more solubility of berseem nutrients. And, although, quinoa silage indicated higher content of NFE (64.16\%, Table 1), it showed lower NFE digestion coefficient, this might be related to its content of some anti- nutritional factors (tannins and saponins, etc..). Data presented in Table (3) showed the nutritive values of the experimental rations expressed as TDN and DCP \%. Higher $(\mathrm{P}<0.05)$ feeding value expressed either as TDN or DCP was shown by rations contained berseem hay or corn silage $(62.52,8.48 ; 61.98$ and $8.78 \%$, respectively).

Table (3): Feed intake, digestion coefficients and nutritive values of experimental rations (mean $\pm \mathrm{SE}$ ).

\begin{tabular}{|l|l|l|l|l|}
\hline \multirow{2}{*}{ Item } & \multicolumn{2}{|c|}{ Hay } & \multicolumn{2}{c|}{ Silage } \\
\cline { 2 - 5 } & Berseem & Quinoa & Corn & Quinoa \\
\hline \multicolumn{5}{|c|}{ DM intake $(\mathrm{g} / \mathrm{h} / \mathrm{d})$} \\
\hline DMI (g/h/d) & $591.99 \pm 12.52^{\mathrm{a}}$ & $438.60 \pm 21.23^{\mathrm{c}}$ & $631.29 \pm 14.23^{\mathrm{a}}$ & $495.15 \pm 21.85^{\mathrm{b}}$ \\
\hline \multicolumn{5}{|c|}{ Digestion coefficients $(\%)$} \\
\hline DM & $64.24 \pm 0.56^{\mathrm{a}}$ & $62.08 \pm 0.48^{\mathrm{b}}$ & $64.05 \pm 0.39^{\mathrm{a}}$ & $62.07 \pm 0.42^{\mathrm{b}}$ \\
\hline OM & $65.70 \pm 0.33^{\mathrm{a}}$ & $63.22 \pm 0.41^{\mathrm{b}}$ & $64.95 \pm 0.37^{\mathrm{a}}$ & $63.40 \pm 0.27^{\mathrm{b}}$ \\
\hline CP & $61.27 \pm 0.28^{\mathrm{b}}$ & $59.48 \pm 0.37^{\mathrm{c}}$ & $63.01 \pm 0.42^{\mathrm{a}}$ & $60.89 \pm 0.25^{\mathrm{b}}$ \\
\hline CF & $56.36 \pm 0.53^{\mathrm{d}}$ & $59.51 \pm 0.49^{\mathrm{b}}$ & $58.56 \pm 0.47^{\mathrm{c}}$ & $61.35 \pm 0.32^{\mathrm{a}}$ \\
\hline EE & $65.37 \pm 0.47^{\mathrm{a}}$ & $62.94 \pm 0.55^{\mathrm{b}}$ & $65.82 \pm 0.35^{\mathrm{a}}$ & $66.68 \pm 0.37^{\mathrm{a}}$ \\
\hline NFE & $68.66 \pm 0.62^{\mathrm{a}}$ & $65.13 \pm 0.58^{\mathrm{b}}$ & $66.71 \pm 0.28^{\mathrm{b}}$ & $64.52 \pm 0.44^{\mathrm{c}}$ \\
\hline \multicolumn{5}{|c|}{ Nutritive values $(\%)$} \\
\hline TDN $(\%)$ & $62.52 \pm 0.27^{\mathrm{a}}$ & $60.23 \pm 0.32^{\mathrm{b}}$ & $61.98 \pm 0.29^{\mathrm{a}}$ & $60.49 \pm 0.33^{\mathrm{b}}$ \\
\hline DCP $(\%)$ & $8.48 \pm 0.22^{\mathrm{a}}$ & $8.35 \pm 0.19^{\mathrm{b}}$ & $8.78 \pm 0.15^{\mathrm{a}}$ & $8.24 \pm 0.26^{\mathrm{b}}$ \\
\hline
\end{tabular}

a,b,c and d Means within rows with different superscripts are significantly different $(\mathrm{P}<0.05)$

These could be related to their higher digestibility of most nutrients. It was clear that this was reflected also on animals feed intake expressed as $\mathrm{DMI} / \mathrm{g} / \mathrm{h} / \mathrm{d}$, whereas animals fed rations contained either berseem hay or corn silage consumed (591.99 and 631.29 $\mathrm{g} / \mathrm{h} / \mathrm{d})$, while those fed quinoa hay or silage consumed (438.60 and 495.15 $\mathrm{g} / \mathrm{h} / \mathrm{d})$, respectively.

\subsection{Some ruminal fermentation measurements}

Digestion in the ruminant has a special nature due to the rumen and its microflora. Several workers indicated that although the type of the microorganisms in the rumen differed significantly, the ultimate main end products are ammonia and TVFA's. The ruminal $\mathrm{pH}$ value is a result of the changes occurred in quantities of rumen metabolites (El-Shazly et al., 1963; Hungate, 1967).

\subsection{Ruminal $p H$}

Data presented in Table (4) showed that ruminal $\mathrm{pH}$ value was decreased with advancing of sampling time and reached 
their minimum value at three hrs. post feeding. The overall mean of ruminal $\mathrm{pH}$ showed insignificant difference $(\mathrm{P}>0.05)$ among different experimental groups. Feeding quinoa silage showed lower ruminal $\mathrm{pH}$ value (6.43) and without significant differences with the corn silage. However, the $\mathrm{pH}$ value of both berseem hay and corn silage was in the range listed by many investigators (ElBeltagi 1998; Elgzar 2007; Rakha, 1988). But unfortunately, quinoa didn't have any previous data concerning ruminal $\mathrm{pH}$ values.

Table (4): $\mathrm{pH}$ value of rumen liquor for sheep fed the experimental rations (mean \pm $\mathrm{SE})$.

\begin{tabular}{|c|c|c|c|c|}
\hline \multirow{2}{*}{ Time } & \multicolumn{2}{|c|}{ Hay } & \multicolumn{2}{c|}{ Silage } \\
\cline { 2 - 5 } & Berseem & Quinoa & Corn & Quinoa \\
\hline 0 & $6.74 \pm 0.38$ & $6.69 \pm 0.44$ & $6.64 \pm 0.42$ & $6.61 \pm 0.33$ \\
\hline 1 & $6.51 \pm 0.54$ & $6.49 \pm 0.48$ & $6.44 \pm 0.26$ & $6.41 \pm 0.39$ \\
\hline 3 & $6.30 \pm 0.41$ & $6.24 \pm 0.52$ & $6.16 \pm 0.33$ & $6.11 \pm 0.31$ \\
\hline 6 & $6.68 \pm 0.28$ & $6.61 \pm 0.41$ & $6.58 \pm 0.37$ & $6.57 \pm 0.28$ \\
\hline Overall mean & $6.56 \pm 0.10$ & $6.51 \pm 0.11$ & $6.46 \pm 0.11$ & $6.43 \pm 0.12$ \\
\hline
\end{tabular}

\subsection{Ruminal $\mathrm{NH}_{3}-\mathrm{N}$}

Ruminal ammonia-N concentration and rate of ammonia production were presented in (Table 5). The mean values of ammonia- $\mathrm{N}$ concentration before feeding (at 0 time) ranged from 12.64 to $14.75(\mathrm{mg} / 100 \mathrm{ml})$ indicating significant differences. The values increased to its maximum level at three hrs post feeding, and then it decreased again at $6 \mathrm{hrs}$ post feeding. These results were in agreement with these obtained by Abdel-Aziz et al. (1993) and El-Ashry et al. (1997).

Table (5): Ammonia nitrogen concentration $(\mathrm{mg} / 100 \mathrm{ml})$ and rate of ammonia production $(\mathrm{mg} / 100 \mathrm{ml} / \mathrm{hr})$ in rumen liquor for sheep fed the experimental rations (mean $\pm \mathrm{SE})$.

\begin{tabular}{|c|c|c|c|c|}
\hline \multirow{2}{*}{ Time } & \multicolumn{2}{|c|}{ Hay } & \multicolumn{2}{|c|}{ Silage } \\
\hline & Berseem & Quinoa & Corn & Quinoa \\
\hline \multicolumn{5}{|c|}{ Ammonia nitrogen concentration $(\mathrm{mg} / 100 \mathrm{ml})$} \\
\hline 0 & $12.64 \pm 0.28^{b}$ & $14.75 \pm 0.17^{\mathrm{a}}$ & $12.89 \pm 0.22^{b}$ & $14.66 \pm 0.54^{a}$ \\
\hline 1 & $13.95 \pm 0.33^{\mathrm{b}}$ & $15.99 \pm 0.37^{\mathrm{a}}$ & $14.26 \pm 0.27^{\mathrm{b}}$ & $16.03 \pm 0.31^{\mathrm{a}}$ \\
\hline 3 & $16.65 \pm 0.32^{b}$ & $18.89 \pm 0.21^{\mathrm{a}}$ & $17.03 \pm 0.31^{b}$ & $1898 \pm 0.38^{a}$ \\
\hline 6 & $12.99 \pm 0.29^{b}$ & $14.93 \pm 0.27^{\mathrm{a}}$ & $13.26 \pm 0.22^{b}$ & $14.99 \pm 0.31^{\mathrm{a}}$ \\
\hline Overall mean & $14.06 \pm 0.21^{\mathrm{b}}$ & $16.14 \pm 0.26^{\mathrm{a}}$ & $14.36 \pm 0.24^{\mathrm{b}}$ & $16.17 \pm 0.28^{a}$ \\
\hline \multicolumn{5}{|c|}{ Rate of Ammonia production $(\mathrm{mg} / 100 \mathrm{ml} / \mathrm{hr}$ ) } \\
\hline 0 & $2.16 \pm 0.22^{b}$ & $2.54 \pm 0.32^{\mathrm{a}}$ & $2.21 \pm 0.18^{b}$ & $2.62 \pm 0.33^{\mathrm{a}}$ \\
\hline 1 & $2.48 \pm 0.29^{b}$ & $2.79 \pm 0.24^{\mathrm{a}}$ & $2.55 \pm 0.21^{b}$ & $2.87 \pm 0.27^{\mathrm{a}}$ \\
\hline 3 & $2.99 \pm 0.18^{b}$ & $3.28 \pm 0.22^{\mathrm{a}}$ & $2.03 \pm 0.38^{b}$ & $3.45 \pm 0.55^{\mathrm{a}}$ \\
\hline 6 & $2.22 \pm 0.33^{\mathrm{b}}$ & $2.76 \pm 0.37^{\mathrm{a}}$ & $2.28 \pm 0.11^{\mathrm{b}}$ & $2.79 \pm 0.31^{\mathrm{a}}$ \\
\hline Overall mean & $2.46 \pm 0.19^{b}$ & $2.84 \pm 0.15^{\mathrm{a}}$ & $2.52 \pm 0.18^{b}$ & $2.93 \pm 0.14^{\mathrm{a}}$ \\
\hline
\end{tabular}

$\mathrm{a}$ and $\mathrm{b}$ Means within rows with different superscripts are significantly different $(\mathrm{P}<0.05)$. 
The mean values of ammonia-N concentration at one hrs, three hrs, and 6hrs, after feeding were higher $(\mathrm{P}<0.05)$ for quinoa hay and quinoa silage compared with the other tested rations, but the lower values $(\mathrm{P}<0.05)$ were obtained for berseem hay and corn silage. Similar trends were observed for rate of ammonia $\mathrm{N}$ production (mg / $100 \mathrm{ml} /$ hr), where berseem hay and corn silage recorded lower rate of ammonia production (mg/ $100 \mathrm{ml} / \mathrm{hr}$ ) without significant difference $(\mathrm{P}<0.05)$ compared to quinoa rations at 0 time which increased to its maximum level at three hrs post feeding, and for different groups then it decreased again at 6 hrs post feeding. Quinoa hay and silage recorded the higher $(\mathrm{P}<0.05)$ values than that of berseem hay and corn silage, but without significant difference within either the former or later group.

\subsection{Total VFA's concentration}

Lower $(\mathrm{P}<0.05)$ TVFA's concentration and rate of TVFA's production were shown by ewes fed quinoa hay or quinoa silage rations (Table 6). Ewes fed berseem hay and those fed corn silage showed higher $(\mathrm{P}<0.05)$ concentration and rate of TVFA's production before feeding, than ewes fed quinoa as hay or silage form.

Table (6): Total volatile fatty acid concentration and rate of TVFA's in rumen liquor of sheep fed the experimental rations (mean $\pm \mathrm{SE}$ ).

\begin{tabular}{|c|c|c|c|c|}
\hline \multirow{2}{*}{ Time } & \multicolumn{2}{|c|}{ Hay } & \multicolumn{2}{|c|}{ Silage } \\
\hline & Berseem & Quinoa & Corn & Quinoa \\
\hline \multicolumn{5}{|c|}{ Total volatile fatty acid concentration } \\
\hline 0 & $9.65 \pm 0.22^{\mathrm{a}}$ & $8.32 \pm 0.17^{\mathrm{b}}$ & $9.44 \pm 0.17^{\mathrm{a}}$ & $8.38 \pm 0.27^{b}$ \\
\hline 1 & $10.42 \pm 0.37^{\mathrm{a}}$ & $9.73 \pm 0.27^{\mathrm{b}}$ & $10.28 \pm 0.21^{\mathrm{a}}$ & $9.88 \pm 0.35^{\mathrm{b}}$ \\
\hline 3 & $12.88 \pm 0.27^{\mathrm{a}}$ & $11.26 \pm 0.36^{\mathrm{b}}$ & $12.26 \pm 0.31^{\mathrm{a}}$ & $11.31 \pm 0.41^{b}$ \\
\hline 6 & $10.18 \pm 0.25^{\mathrm{a}}$ & $9.11 \pm 0.17^{\mathrm{b}}$ & $9.93 \pm 0.15^{\mathrm{a}}$ & $9.48 \pm 0.33^{\mathrm{b}}$ \\
\hline Overall mean & $10.78 \pm 0.72^{\mathrm{a}}$ & $9.61 \pm 0.62^{\mathrm{b}}$ & $10.48 \pm 0.61^{\mathrm{a}}$ & $9.76 \pm 0.59^{b}$ \\
\hline \multicolumn{5}{|c|}{ Rate of total volatile fatty acid } \\
\hline 0 & $2.55 \pm 0.14^{\mathrm{a}}$ & $2.01 \pm 0.11^{\mathrm{b}}$ & $2.38 \pm 0.12^{\mathrm{a}}$ & $1.99 \pm 0.16^{\mathrm{b}}$ \\
\hline 1 & $2.94 \pm 0.21^{\mathrm{a}}$ & $2.42 \pm 0.19^{b}$ & $2.78 \pm 0.33^{\mathrm{a}}$ & $2.22 \pm 0.31^{\mathrm{b}}$ \\
\hline 3 & $3.42 \pm 0.29^{\mathrm{a}}$ & $2.88 \pm 0.22^{b}$ & $3.06 \pm 0.22^{\mathrm{a}}$ & $2.69 \pm 0.15^{b}$ \\
\hline 6 & $2.73 \pm 0.25^{\mathrm{a}}$ & $2.14 \pm 0.15^{b}$ & $2.55 \pm 0.23^{\mathrm{a}}$ & $2.05 \pm 0.16^{b}$ \\
\hline Overall mean & $2.91 \pm 0.19^{a}$ & $2.36 \pm 0.21^{\mathrm{b}}$ & $2.69 \pm 0.14^{\mathrm{a}}$ & $2.24 \pm 0.16^{b}$ \\
\hline
\end{tabular}

$\mathrm{a}$ and $\mathrm{b}$ Means within rows with different superscripts are significantly different $(\mathrm{P}<0.05)$.

Values increased to its maximum level at three hrs, post feeding and then it decreased again at $6 \mathrm{hrs}$, post feeding. The mean values of TVFA's concentration and rate of TVFA's production at one hr, three and 6hrs after feeding followed the same trend. The overall mean of TVFA's concentration and rate of TVFA's production values showed insignificant difference for ewes fed Berseem hay and corn silage, however they indicated higher $(\mathrm{P}<0.05)$ values in compare with ewes fed quinoa as hay or silage. 


\subsection{Rumen volume}

Rumen volume (L) of sheep fed the experimental rations is presented in Table (7). Rumen volume was decreased with the advancing time of feeding; it reached their minimum values at $6 \mathrm{hr}$ post feeding. Maximum rumen volume values were observed at 0 time before feeding for all rations. Ewes fed corn silage indicated the higher value without significant difference $(\mathrm{P}>0.05)$ with those fed berseem hay. Ewes fed quinoa hay or silage indicated lower $(\mathrm{P}<0.05)$ values. The lower rumen volume was for ewes fed quinoa hay $(3.17 \mathrm{~L})$.

Table (7): Rumen volume (L) of sheep fed the experimental rations (mean $\pm \mathrm{SE}$ ).

\begin{tabular}{|c|l|l|l|l|}
\hline \multirow{2}{*}{ Time } & \multicolumn{2}{|c|}{ Hay } & \multicolumn{2}{c|}{ Silage } \\
\cline { 2 - 5 } & Berseem & Quinoa & Corn & Quinoa \\
\hline 0 & $3.86 \pm 0.17^{\mathrm{a}}$ & $3.42 \pm 0.05^{\mathrm{b}}$ & $3.88 \pm 0.13^{\mathrm{a}}$ & $3.47 \pm 0.25^{\mathrm{b}}$ \\
\hline 3 & $3.59 \pm 0.11^{\mathrm{a}}$ & $3.16 \pm 0.18^{\mathrm{b}}$ & $3.54 \pm 0.15^{\mathrm{a}}$ & $3.19 \pm 0.06^{\mathrm{b}}$ \\
\hline 6 & $3.25 \pm 0.09^{\mathrm{a}}$ & $2.94 \pm 0.14^{\mathrm{b}}$ & $3.22 \pm 0.21^{\mathrm{a}}$ & $3.01 \pm 0.15^{\mathrm{b}}$ \\
\hline Overall mean & $3.57 \pm 0.18^{\mathrm{a}}$ & $3.17 \pm 0.14^{\mathrm{b}}$ & $3.55 \pm 0.19^{\mathrm{a}}$ & $3.22 \pm 0.13^{\mathrm{b}}$ \\
\hline
\end{tabular}

$\mathrm{a}$ and $\mathrm{b}$ Means within rows with different superscripts are significantly different $(\mathrm{P}<0.05)$.

\subsection{Rate of outflow}

Rate of outflow (\% hrs) from rumen of sheep fed the experimental rations were summarized in (Table 8). The values increased to its maximum level at $6 \mathrm{hrs}$, post feeding. The mean values of rate of outflow (\% hr) at one hrs, three hrs, and 6 hrs, after feeding were higher $(\mathrm{P}<0.05)$ for quinoa hay and quinoa silage compared to other rations, but the lower $(\mathrm{P}<0.05)$ value was obtained for berseem hay and corn silage rations.

\subsection{Ruminal microbial nitrogen}

Microbial nitrogen ( $\mathrm{MN} \mathrm{g} / \mathrm{d})$ in the rumen of sheep fed the experimental rations were illustrated in (Table 9). Values were decreased with the advancing time to reach their minimum values at $6 \mathrm{hrs}$ for different experimental groups. Berseem hay group was the higher one without significant difference $(\mathrm{P}>0.05)$ with those of corn silage. Quinoa silage and quinoa hay yielded the lower $(\mathrm{MN} / \mathrm{g} / \mathrm{d})$.

Table (8): Rate of outflow (\%/hrs) from rumen of sheep fed the experimental rations (mean $\pm \mathrm{SE}$ ).

\begin{tabular}{|c|l|l|l|l|}
\hline \multirow{2}{*}{ Time } & \multicolumn{2}{|c|}{ Hay } & \multicolumn{2}{c|}{ Silage } \\
\cline { 2 - 5 } & Berseem & Quinoa & Corn & Quinoa \\
\hline 0 & $5.33 \pm 0.32^{\mathrm{b}}$ & $5.89 \pm 0.22^{\mathrm{a}}$ & $5.31 \pm 0.37^{\mathrm{b}}$ & $5.82 \pm 0.25^{\mathrm{a}}$ \\
\hline 3 & $5.69 \pm 0.28^{\mathrm{b}}$ & $6.04 \pm 0.18^{\mathrm{a}}$ & $5.72 \pm 0.31^{\mathrm{b}}$ & $5.99 \pm 0.33^{\mathrm{a}}$ \\
\hline 6 & $5.87 \pm 0.33^{\mathrm{b}}$ & $6.38 \pm 0.25^{\mathrm{a}}$ & $5.90 \pm 0.28^{\mathrm{b}}$ & $6.26 \pm 0.27^{\mathrm{a}}$ \\
\hline Overall mean & $5.63 \pm 0.16^{\mathrm{b}}$ & $6.10 \pm 0.14^{\mathrm{a}}$ & $5.64 \pm 0.17^{\mathrm{b}}$ & $6.02 \pm 0.13^{\mathrm{a}}$ \\
\hline
\end{tabular}

$\mathrm{a}$ and $\mathrm{b}$ Means within rows with different superscripts are significantly different $(\mathrm{P}<0.05)$. 
Table (9): Microbial nitrogen ( $\mathrm{MN} \mathrm{g/d}$ ) in the rumen of sheep fed the experimental rations (mean $\pm \mathrm{SE}$ ).

\begin{tabular}{|c|l|l|l|l|}
\hline \multirow{2}{*}{ Time } & \multicolumn{2}{|c|}{ Hay } & \multicolumn{2}{c|}{ Silage } \\
\cline { 2 - 5 } & Berseem & Quinoa & Corn & Quinoa \\
\hline 0 & $16.33 \pm 0.33^{\mathrm{a}}$ & $14.53 \pm 0.26^{\mathrm{b}}$ & $16.07 \pm 0.17^{\mathrm{a}}$ & $14.71 \pm 0.22^{\mathrm{b}}$ \\
\hline 3 & $15.94 \pm 0.17^{\mathrm{a}}$ & $14.16 \pm 0.22^{\mathrm{b}}$ & $15.83 \pm 0.09^{\mathrm{a}}$ & $14.22 \pm 0.28^{\mathrm{b}}$ \\
\hline 6 & $15.87 \pm 0.25^{\mathrm{a}}$ & $13.63 \pm 0.18^{\mathrm{b}}$ & $15.55 \pm 0.11^{\mathrm{a}}$ & $13.96 \pm 0.21^{\mathrm{b}}$ \\
\hline Overall mean & $16.05 \pm 0.14^{\mathrm{a}}$ & $14.11 \pm 0.26^{\mathrm{b}}$ & $15.82 \pm 0.15^{\mathrm{a}}$ & $14.30 \pm 0.22^{\mathrm{b}}$ \\
\hline
\end{tabular}

$\mathrm{a}$ and $\mathrm{b}$ Means within rows with different superscripts are significantly different $(\mathrm{P}<0.05)$.

\section{Conclusion}

On the light of in vivo and in vitro results, it was concluded that quinoa silage or hay could substitute some medium quality roughages in sheep rations and could share to somehow in solving shortage in summer available forage in Egypt.

\section{References}

Abd El- Malik, W. H. (1972), Some nutritional studies on silage making from clover ryegrass mixture for feeding dairy cattle, Ph.D. Thesis, Faculty of Agriculture, Cairo University, Egypt.

Abd El-Aziz, A. A., Lashin, M. E., ElOksh, H. and Fouad, R. T. (1993), 'Effect of some mechanical treatments and feed nutritional additives on nutritional value of corn stalks. II. Feeding trials ", Journal Agriculture Science, Mansoura University, Vol. 18, No. 1, pp. 4654.

Al-Rabbat, M. F., Badwin, R. L. and Weir, W. C. (1971), "In Vitro nitrogen- tracer technique for some kinetic measures of rumen ammonia", Journal of Dairy Science, Vol. 54 No. 8, pp. 11501161.

AOAC (2012), Official methods of analysis, $19^{\text {th }}$ ed., Association of Official Analytical Chemists, Gaithersburg, USA.

Barrio, J. R., Owens, F. N. and Goetsch, A. L. (1985), "Soluble nutrients in protein supplements and in situ disappearance", Canadian Journal of Animal Science, Vol. 65, pp. 667672.

Borhami, B. E. A., El- Shazly, K., AbouAkkada, A. R., Naga, M. A., Nour, A. M. and Abaza, M. A. (1979), "Nitrogen (15N) Utilization and microbial protein synthesis in the rumen of urea fed cattle", Journal of Animal Science, Vol. 49 No. 5, pp. 1306-1311.

Borhami, B. E. A., Fahmy, W. G. and ElShazly, K. (1992), Rumen environment, microbial protein synthesis and nitrogen balance in sheep, Proceedings of "Manipulation of rumen micro-organisms" International Conference, Alexandria, Egypt. 
Carrol, E. J. and Hungate, R. E. (1954), "The magnitude of microbial fermentation in the bovine rumen", Journal of Applied Microbiology, Vol. 2, pp. 205-214.

Church, D. C. (1980), Digestive Physiology and Nutrition of Ruminants: Practical Nutrition (3), $2^{\text {nd }}$ Ed., O \& B Books, Inc., USA.

Duncan, D. B. (1955), "Multiple range and multiple F-test", Biometrics, Vol. 11, pp. 1-42.

El- Shazly, K. and Hungate, R. E. (1965), "Fermentation capacity as measure of net growth of rumen microorganism", Applied Microbiology, Vol. 13, pp. 62-69.

El-Ashry, M. A., Ahmed, M. F., ElSaadany, S. A., Youssef, M. E. S., Gomaa, J. A. and Deraz, T. A. A. (1997), "Effect of mechanical vs. Mechano-Chemical or MechanoBiochemical treatments of cropresidues on their use in ruminant rations, digestibility, nitrogen balance and some blood and rumen liquor parameters of sheep", Egyptian Journal Nutrition and Feeds, Vol. 1, pp. 173-186.

El-Beltagi, E. A. A. (1998), Feeding ruminants with treated berseem as silage or hay to raise their nutritive value, M.Sc. Thesis, Faculty of Agriculture, Kafr El-Sheikh, Tanta University, Egypt.

El-gzar, M. E. T. (2007), Evaluation of silage made from residues of some hybrid of maize, M.Sc. Thesis,
Faculty of Agriculture, Al-Azhar University, Egypt.

El-shazly, K. (1958), "Studies on the nutritive value of some common Egyptian feedingstuffs. I. Nitrogen retention and ruminal ammonia curves", Journal of Agricultural Science, Vol. 51 No. 2, pp. 149-156.

El-Shazly, K., Abou Akkada, A. R. and Naga, M. A. (1963), "The use of the in vitro fermentation techniques to estimate the digestible energy content of some Egyptian forages. III. The in vitro production of volatile fatty acids as criteria", Journal of Agricultural Science, Vol. 73 No. 3, pp. 431-436.

El-Shazly, K., Ahmed, E. I. A., Naga, M. A. and Borhami, B. E. A. (1976), "A colorimetric technique using chromium-ethylene diamine tetra acetate for measuring rumen volume", Journal of Agricultural Science, Vol. 87 No. 2, pp. 369-373.

Everson, R. A., Jorgensen, N. A. and Barrington, G. P. (1971), "Effect of bentonite, nitrogen source and stage of maturity on nitrogen redistribution in corn silage", Journal of Dairy Science, Vol. 54, pp. 1482-1490.

Hanafy, M. A. (1985), Nutritional evaluation of ensiled by products with or without forage, Ph.D. Thesis, Faculty of Agriculture, Cairo University, Egypt.

Hungat, R. E. (1967), The Rumen and its 
microbes, Academic Press, New York, USA.

Hungate, R. E. (1965), Quantitive aspects of the rumen fermentation. In physiology of Digestion in the ruminant, Butterworth's Inc., Washington, DC, USA.

Lorenz, K. (1990), "Quinoa (Chenopodium quinoa) starchphysicochemical properties and functional characteristics", StarchStarke, Vol. 42, pp. 81-86.

NRC (2007), Nutrient requirement of small ruminants: sheep, goats, cervids, and new world camelids, National Academy of Sciences, Washington, DC, USA.

Papastylianou, P., Kakabouki, I., Tsiplakou, E., Travlos, I., Bilalis, D., Hela, D., Chachalis, D., Anogiatis, G. and Zervas, G. (2014), "Effect of fertilization on yield and quality ofbiomass of quinoa (Chenopodium quinoa Willd.) and green amaranth (Amaranthus retroflexus L.)", Bulletin of the University of Agricultural Sciences and Veterinary Medicine Cluj-Napoca Horticulture, Vol. 71 No. 2, pp. 288-292.

Rakha, G. M. (1988), Studies on the effect of using agro-industrial byproducts on health and production of some animal farms, Ph.D. Thesis, Faculty of Agriculture, Cairo University, Egypt.

SAS, (2002), SAS User's Guide
Statistics, Statistical Analysis System, SAS Institute Inc., Cary, NC.

Tabana, A. S. (1994), Utilization of corn and sunflower plant residues in ruminants nutrition, M.Sc. Thesis, Faculty of Agriculture, Cairo University, Egypt.

Van Soest, P. J., Robertson, J. D. and Lewis, B. A. (1991), "Methods for dietary fibre, neutral detergent fiber and non-starch polysaccharides in relation to animal nutrition", Journal of Dairy Science, Vol. 74, pp. 3583 3597.

Walker, D. J. (1965), "Energy metabolism and rumen microorganisms", In Physiology of digestion in the ruminants, Butterworth Inc., Washington, DC, USA.

Warner, A. C. I. (1964), "Production of volatile fatty acids in the rumen, methods of measurement", Nutrition Abstracts and Reviews, Vol. 34, pp. 339.

Weber, E. J. (1978), "The Inca's ancient answer to food shortage", Nature, Vol. 272, pp. 486.

Wilkinson, J. M., Wadephul, F. and Hill, J. (1996), Silage in Europe, a survey of 33 countries, Chalcombe Publications, Welton, UK.

Zbigniew, P., Krzysztof, G. and Lucyna, P. (2018), "The influence of additives facilitating ensiling on the 
quality of quinoa (Chenopodium quinoa Willd.) silage", Journal of Central European Agriculture, Vol. 19 No. 3, pp. 607-614.

Zedan, A. H. (1998), Silage of corn stalks and sugar can tops in dairy cow rations, M.Sc. Thesis, Faculty of Agriculture, Cairo University, Egypt 